\title{
DIPHENYLAMINE REACTION IN CHRONIC JOINT DISEASES
}

\author{
BY \\ MILAN ADAM, JIŘí MALECEK, AND MARTA KU゚TOVÁ \\ From the Research Institute for Rheumatic Diseases, Prague \\ WITH STATISTICAL COLLABORATION BY \\ VLADIMÍR MALÝ \\ From the Institute of Public Health Organization, Charles University, Prague, Czechoslovakia
}

(RECEIVED FOR PUBLICATION DECEMBER 19, 1956)

Niazi and State (1948) found that protein-free precipitate of plasma or serum heated in a boiling water bath with Dische's diphenylamine reagent gave a dark purple colour in certain diseases, especially in malignancy and inflammatory diseases, such as rheumatoid arthritis, rheumatic fever, subacute bacterial endocarditis, empyema, and tuberculosis (Dische, 1929, 1930).

The value of this diphenylamine reaction as an index of rheumatic fever activity has been attested by Ayala, Moore, and Hess (1951), Coburn, Moore, and Haninger (1953), Coburn and Haninger (1954), and Coburn, Bates, Hahn, and Murphy (1956), but opinions differ as to its value in chronic joint diseases (Cecchi and Ferraris, 1955; Fearnley, Purkis, de Coek, Lackner, and Meanock, 1955; Förster and Schmid, 1955; Rother, 1955; Gamp, 1955). We have therefore analysed diphenylamine levels in chronic joint diseases, and have correlated them with the non-glucosamine serum polysaccharide and mucoprotein levels, to elucidate the relation between these three reactions.

\section{Material}

Controls. -25 men and 25 women with no evidence of any disease.

Patients. -100 patients with rheumatoid arthritis, of whom fifty were in the second stage, and fifty in the third or fourth stage*; fifty patients with ankylosing spondylitis; and fifty patients with degenerative joint diseases, sometimes accompanied by a secondary inflammatory process.

We excluded patients with other concurrent diseases.

Since there was no difference between the levels in

\footnotetext{
- Steinbrocker, Traeger, and Batterman (1949).
}

normal men and women, we did not differentiate between the sexes in our groups of patients.

\section{Methods}

Diphenylamine Reaction.-The semimicro procedure described by Ayala and others (1951) was used. The readings were made with a model 6A Coleman spectrophotometer at $530 \mathrm{~m} \mu$, and the results were given at optical density $\times 1,000$. The erythrocyte sedimentation rate was determined by the method of Westergren (1926), the mucoprotein-tyrosine by the method of Winzler, Devor, Mehl, and Smyth (1948), and the non-glucosamine serum polysaccharides by the method of Shetlar, Foster, and Everett (1948).

By way of statistical evaluation we calculated the mean $M$ and the standard deviation $S$. In each group the correlation coefficient $\boldsymbol{r}^{*}$ between the diphenylamine levels and other factors was calculated. We compared the difference between the means $d=M_{1}-M_{2}$ with the appropriate standard error. $\dagger$ Analogically, the difference between $S$ values was evaluated by means of the standard error of the difference of two standard deviations (which equals $S_{d} / \sqrt{2}$ ). The difference $M_{1}-M_{2}$ and $S_{1}-S_{2}$, respectively, was recorded as significant where it exceeded twice the respective standard error; if the difference exceeded three times the standard error, we considered it as highly significant.

The significance of $\boldsymbol{r}$ values was ascertained by means of Tables for 48 degrees of freedom; $r$ values exceeding the 5 per cent. level $(0 \cdot 2789)$ were recorded as significant, and those exceeding the 1 per cent. level $(0 \cdot 3613)$ as highly significant.

$$
r=\frac{\Sigma_{x y}-\frac{\Sigma_{x} \Sigma_{v}}{n}}{n \sigma_{x} \sigma_{y}} \quad+s_{d}=\sqrt{\bar{S}_{1}^{2}+\bar{s}_{2}^{2}} / \sqrt{50}
$$




\section{Results}

Control Group.-The mean diphenylamine level was $0 \cdot 311$ (range $0 \cdot 250-0 \cdot 350$ ) and the standard deviation 0.024 (Table I).

Ankylosing Spondylitis.-The mean was 0.354 and the standard deviation 0.041. Levels higher than 0.350 (the limit in normal subjects) were ascertained in 25 subjects, the highest being 0.430 .

Second Stage Rheumatoid Arthritis.-39 patients had levels higher than 0.350 (mean 0.419 ; standard deviation 0.096).

Third or Fourth Stage Rheumatoid Arthritis.-The mean level was 0.434 and the standard deviation $0 \cdot 078$. In only eight patients was the level lower than $0 \cdot 350$.
Degenerative Joint Disease.-The mean level was 0.334 and the standard deviation 0.036 . In only fifteen patients was the level higher than $0 \cdot 350$.

The significance of the difference between these means is included in Table II.

The correlation coefficients between the diphenylamine and non-glucosamine polysaccharide levels in all groups of patients were found to be highly significant, but this was not the case with the correlation coefficients between the diphenylamine and mucoprotein levels, except in the group with third or fourth stage rheumatoid arthritis (Table III).

\section{Discussion}

The substance which gives the purple colour after heating with the diphenylamine reagent is probably

TABLE I

MEAN AND STANDARD DEVIATION OF THE DIPHENYLAMINE REACTION

\begin{tabular}{|c|c|c|c|c|c|}
\hline \multirow[b]{2}{*}{ Condition } & \multirow[b]{2}{*}{ Normal } & \multirow{2}{*}{$\begin{array}{l}\text { Degenerative } \\
\text { Joint Disease }\end{array}$} & \multirow{2}{*}{$\begin{array}{l}\text { Ankylosing } \\
\text { Spondylitis }\end{array}$} & \multicolumn{2}{|c|}{ Rheumatoid Arthritis } \\
\hline & & & & Second Stage & Third or Fourth Stage \\
\hline No. of Cases & 50 & 50 & 50 & 50 & 50 \\
\hline Mean & $0 \cdot 311$ & $0 \cdot 334$ & $0 \cdot 354$ & 0.419 & 0.434 \\
\hline Standard Deviation & 0.024 & 0.036 & 0.041 & 0.096 & 0.078 \\
\hline
\end{tabular}

TABLE II

STATISTICAL COMPARISON OF DIPHENYLAMINE REACTION RESULTS

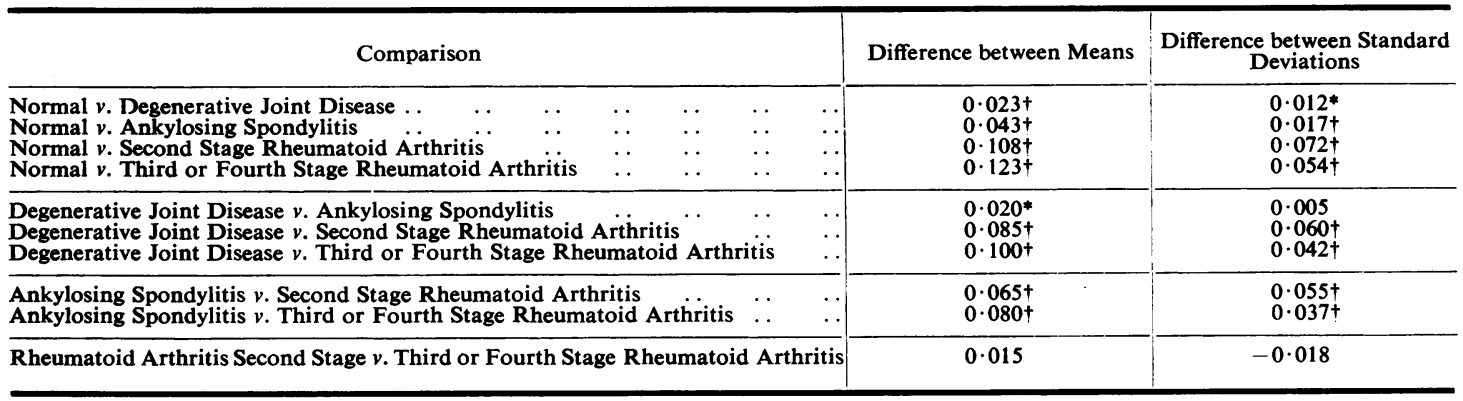

* Significant at the 5 per cent. level.

$\dagger$ Significant at the 1 per cent. level.

TABLE III

SUMMARY OF STATISTICAL COMPARISONS OF CORRELATION COEFFICIENTS

\begin{tabular}{|c|c|c|c|c|c|}
\hline \multirow{2}{*}{ Correlation Between } & \multirow{2}{*}{ Normal } & \multirow{2}{*}{$\begin{array}{c}\text { Degenerative } \\
\text { Joint } \\
\text { Disease }\end{array}$} & \multirow{2}{*}{$\begin{array}{l}\text { Ankylosing } \\
\text { Spondylitis }\end{array}$} & \multicolumn{2}{|c|}{ Rheumatoid Arthritis } \\
\hline & & & & Second Stage & Third or Fourth Stage \\
\hline $\begin{array}{c}\text { Diphenylamine Reaction and Muco- } \\
\text { protein Tyrosine }\end{array}$ & $0 \cdot 229$ & $0 \cdot 286 t$ & $0 \cdot 252$ & $0 \cdot 139$ & $0 \cdot 740^{*}$ \\
\hline $\begin{array}{l}\text { Diphenylamine Reaction and Non- } \\
\text { glucosamine Serum Polysaccharides }\end{array}$ & $0 \cdot 219$ & $0.562 *$ & $0 \cdot 736^{*}$ & $0 \cdot 517^{*}$ & $0.552 *$ \\
\hline
\end{tabular}

* Significant at the 0.1 per cent. level.

+ Significant at the 5 per cent. level. 
TABLE IV

MEANS AND STANDARD DEVIATIONS OF ERYTHROCYTE SEDIMENTATION RATE

\begin{tabular}{|c|c|c|c|c|c|}
\hline \multirow{2}{*}{\multicolumn{2}{|c|}{ Condition }} & \multirow{2}{*}{$\begin{array}{c}\text { Degenerative } \\
\text { Joint } \\
\text { Disease }\end{array}$} & \multirow{2}{*}{$\begin{array}{l}\text { Ankylosing } \\
\text { Spondylitis }\end{array}$} & \multicolumn{2}{|c|}{ Rheumatoid Arthritis } \\
\hline & & & & Second & Third or Fourth Stage \\
\hline No. of Cases. & . & 50 & 50 & 50 & 50 \\
\hline \multirow{2}{*}{$\mathrm{mm} . / 1 \mathrm{hr}$} & $M$ & $15 \cdot 40$ & $24 \cdot 42$ & $21 \cdot 02$ & $67 \cdot 50$ \\
\hline & 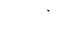 & $9 \cdot 01$ & $14 \cdot 3$ & $19 \cdot 7$ & $28 \cdot 3$ \\
\hline
\end{tabular}

carbohydrate in nature and is contained in the glycoprotein. Ayala and others (1951), Cecchi and Ferraris (1955), and Fearnley and others (1955) are of the opinion that this carbohydrate is associated with serum mucoprotein. In our experience, however, the trichloracetic acid filtrate from serum which contains mucoprotein gives practically no colour with the diphenylamine reagent.

We conclude that the colour reaction is associated with serum glycoprotein as indicated also by the correlations shown with the Shetlar method.

From the practical viewpoint, the highly significant difference of the means of the diphenylamine reaction in second stage rheumatoid arthritis is valuable, not only when compared with that of the control group, but also, and chiefly, when compared with the degenerative joint disease and ankylosing spondylitis groups. The difference of the erythrocyte sedimentation rate is insignificant in comparison with the two latter groups (Table IV).

Cecchi and Ferraris (1955) as well as Gamp (1955) believe that it is quite possible to determine the intensity of an inflammatory process in rheumatoid arthritis in this way. Förster and Schmid (1955), however, and Fearnley and others (1955) see no particular advantage in this method of determining the activity of rheumatoid arthritis. Cecchi and Ferraris (1955) did not find it very useful in their cases of ankylosing spondylitis.

Our experience suggests that the diphenylamine reaction may be used to measure the inflammatory process activity, not only in rheumatic fever, but also in rheumatoid arthritis and ankylosing spondylitis. It is not yet certain whether it will be possible to use the diphenylamine reaction for the differential diagnosis of incipient rheumatoid arthritis from other forms of joint involvement.

\section{Summary}

Sera were examined from five groups, each consisting of fifty subjects. The diphenylamine colour reaction was ascertained by the modified Ayala method, the non-glucosamine serum polysaccharides by the Shetlar method, and the mucoproteins by the Winzler method.
The difference between the mean diphenylamine reaction in second stage rheumatoid arthritis patients, on the one hand, and in the degenerative joint disease and ankylosing spondylitis patients, on the other hand, was highly significant. The difference in the erythrocyte sedimentation rate was not significant. Correlation between the diphenylamine reaction levels and non-glucosamine serum polysaccharide levels was significant at the $0 \cdot 1$ per cent. level in all groups of patients.

Hence, the substance which gives the purple colour is thought to be related rather to the non-glucosamine serum polysaccharides than to mucoprotein. The authors further deduce that the diphenylamine reaction may be used as a measure of the degree of inflammation not only in rheumatic fever but also in rheumatoid arthritis and in ankylosing spondylitis.

\section{REFERENCES}

Ayala, W., Moore, L. V., and Hess, E. L. (1951). J. clin. Invest., 30, 781.

Cecchi, E., and Ferraris, F. (1955). Annals of the Rheumatic Diseases, 14, 267.

Coburn, A. F., Bates, R. C., Hahn, J. W., and Murphy, P. (1956). J. chron. Dis., 3, 140.

- and Haninger, J. (1954). J. exp. Med., 99, 1.

- Moore, L. V., and Haninger, J. (1953). Arch. intern. Med., 92, 185.

Dische, Z. (1929). Mikrochemie, 7, 33.

(1930). Ibid., 8, 4 .

Fearnley, G. R., Purkis, J., de Coek, N., Lackner, R., and Meanock, R. I. (1955). Annals of the Rheumatic Diseases, 14, 226.

Förster, O., and Schmid, J. (1955). Z. Rheumaforsch., 14, 364.

Gamp, A. (1955). Med. Klin., 50, 2146.

Niazi, S., and State, D. (1948). Canc. Res., 8, 653.

Rother, K. (1955). Z. Rheumaforsch., 14, 215.

Shetlar, M. R., Foster, J. V., and Everett, M. R. (1948). Proc. Soc. exp. biol. (N.Y.), 67, 125 .

Steinbrocker, O., Traeger, C. H., and Batterman, R. C. (1949). J. Amer. med. Ass., 140, 659

Westergren, A. (1926). Amer. Rev. Tuberc., 14, 94.

Winzler, R. J., Devor, A. W., Mehi, J. W., and Smyth, I. M. (1948). J. clin. Invest., 27, 609 .

\section{Réaction de la diphénylamine dans les maladies articulaires chroniques \\ RÉSUMÉ}

Les sérums provenant de cinq groupes, chacun de cinquante sujets, one été examinés. On détermina la réaction chromogène de la diphénylamine par la méthode Ayala modifée, les polysaccharides non-glucosamines du sérum par la méthode Shetlar et les mucoprotéines par la méthode Winzler.

La différence entre les chiffres moyens de la réaction de la diphénylamine, d'une part chez les malades atteints d'arthrite rhumatismale au second stade et d'autre part 
chez les malades atteints de maladie articulaire de dégénérescence et de spondylite ankylosante, fut très significative. La différence entre les vitesses de sédimentation erythrocytaire ne fut pas significative. La corrélation entre les chiffres de la réaction de la diphénylamine et ceux des polysaccharides non-glucosamines de serum, fut significative au niveau de $0 \cdot 1$ pour cent, dans tous les groupes de malades.

C'est pourquoi on suppose que la substance qui donne la couleur pourpre est apparentée plutôt aux polysaccharides non-glucosamines de sérum, qu'à la mucoprotéine.

Les auteurs concluent d'autre part que la réaction de la diphénylamine peut être utilisée comme mesure du degré d'inflammation, non seulement dans le rhumatisme articulaire aigu mais aussi dans l'arthrite rhumatismale et dans la spondylite ankylosante.

\section{Reacción de la difenilamina en las enfermedades articulares crónicas \\ Sumario}

Se investigaron los sueros de cinco grupos de cincuenta sujetos en cada grupo. Se determinaron: la reacción cromógena de la difenilamina por el método de Ayala, los polisacaridos no-glucosaminas del suero por el método de Shetlar y las mucoproteinas por el método de Winzler.

Hubo una diferencia muy significativa respecto a las cifras medias de la reacción de la difenilamina entre los enfermos con artritis reumatoide en la segunda etapa y los con una enfermedad articular degenerativa o con la espondilartritis anquilosante. La diferencia entre las velocidades de sedimentacióm eritrocitaria no fué significativa. La correlación entre las cifras de la reacción de la difenilamina y las de los polisacaridos no-glucosaminas del suero fué significativa al nivel de $0,1 \%$ en todos los grupos de enfermos.

Se piensa, pués, que la substancia que da el color morado se relaciona más con los polisacaridos noglucosaminas del suero que con la mucoproteina.

Los autores concluyen, además, que la reacción de la difenilamina se puede emplear para medir el grado de inflamación no sólo en el reumatismo poliarticular agudo, sino también en la artritis reumatoide y en la espondilartritis anquilosante. 